\title{
Nutritional Surveillance in Brazil: Challenges and Opportunities. A Mixed-Method Research to Assess the Brazilian Sisvan System
}

Gabriela Nasser ( $\sim$ gabriela.nasser@mail.medizin.uni-freiburg.de )

University of Freiburg

Andy Maun

University of Freiburg

\section{Research Article}

Keywords: Nutritional surveillance, Malnutrition, Primary Care, Phenomenography

Posted Date: September 7th, 2021

DOI: https://doi.org/10.21203/rs.3.rs-844880/v1

License: (c) (i) This work is licensed under a Creative Commons Attribution 4.0 International License.

Read Full License 


\section{Abstract}

Background: As countries currently face growing malnutrition trends (often with a double burden of malnutrition), data on the nutritional status of the population can provide support to local policies, as well as track progress towards goals, such as the global nutrition targets. Brazil has a national nutritional surveillance system (Sisvan), which provides nutritional status data for municipalities, on all age groups. In an effort to offer a more in-depth analysis of the Sisvan, this study investigated the strengths and limitations of the system regarding the available data on children to explore its contribution to the health information system and policy making potential.

Methods: A mixed methods approach was used innovatively, with triangulation of results, to combine quantitative descriptive statistics (to determine national coverage and completeness of nutritional status data among children in the Sisvan between 2008 and 2018), with a qualitative phenomenographic analysis of in-depth interviews with stakeholders involved with the system.

Results: Results demonstrated on average an increase in coverage within the system of the nutritional status of children nationally from $14 \%$ in 2008 to $35,8 \%$ in 2018 , with variability in this growth over the different areas of the country. The interviews demonstrated that the Sisvan is a tool to improve health conditions that go beyond nutrition. It has the potential to be integrated in a greater structure of Public Health care. After triangulation of results, there was agreements between the quantitative and qualitative analysis, demonstrating that the surveillance system is embedded in the Primary Health Care strategy, albeit current limitations.

Conclusion: The Sisvan has the potential to be an important tool for the monitoring of nutritional targets and provision of information for local and national health and nutrition policies. However, more integration between the several instances involved is still a gap, for a full usage of the system and the generated data.

\section{Background}

The current global Covid-19 pandemic has had a direct effect on levels of food insecurity and malnutrition worldwide [1, 2]. Areas such as Latin America, which had rising levels of nutritional deficiencies, overweight and obesity previous to the onset of the pandemic [3], are suffering devastating effects.

In order to ensure the development of local programs and policies, effective nutritional surveillance is essential. It can provide data on a district or municipal level to assist on planning and tracking progress towards goals and targets [4]. The Brazilian National Nutrition Surveillance System (Sisvan - Sistema de Vigilância Alimentar e Nutricional) has a history that parallels the international guidelines and strategies in nutrition policies and surveillance. It was initiated in the 1970s, following the determination of the first World Food Conference in $1974[5,6]$ and gained strength in the 1990s, aligned with the new Unified Health System (SUS), which brought free health care access to the Brazilian population. For the next 
decade, the system developed further, when in 1999, the National Food and Nutrition National Policy was published, giving the surveillance its main objective of monitoring "the nutritional pattern and status of individuals attended by the SUS, in all courses of life" [7]. The national policy also determined that the system "should continuously describe and predict trends in the conditions and determining factors of the food and nutrition of the population" [7]. The Sisvan system has been through changes since it's digital launch in 2002 and a version called "Sisvan-web" was made available for the municipalities in 2007, being fully online and integrated into the national digital health information system, the e-sus.

Studies done in the last years have pointed to challenges and limitations of the Sisvan however, including: low coverage, insufficient training for data collection and log system, lack of knowledge of the professionals regarding data interpretation and the direct relationship of the data collection process with the cash transfer program Bolsa Familia (Family Allowance), since a majority of the Sisvan coverage is due to measurements done for this initiative $[8,9]$. Literature also indicates there is still a lot to be improved in terms of data collection and management [10-12], becoming evident that national surveillance strategies are still not used in their full capacity at municipal levels $[13,14]$, indicating a gap between the data generated by the system and its final usage [11].

This study used a mixed method approach with triangulation of a quantitative analysis of the system's coverage and qualitative interviews regarding the Sisvan system's data collection and analysis processes. The use of a mixed-method approach to investigate this surveillance tool is innovative in that this combination of quantitative and qualitative methodologies in one study can add complexity and depth [15] into what are the factors influencing the implementation of this nutritional surveillance system and how well it is aligned with its fundamental purpose.

The general objective of this paper is to investigate the strengths and limitations of the Brazilian Nutritional Surveillance System (Sisvan), concerning its contribution to health information systems and policy making potential. As specific objectives, the study aims to:

1. Determine the national coverage and completeness of the nutritional status data among children (5 to 9 years old) in the Sisvan system between 2008 and 2018 by using descriptive statistics;

2. Explore through in-depth interviews, how personnel involved in the collection of data perceive the Sisvan system concerning the definition and achievement of its goals.

3. Assess the strengths and limitations of the Sisvan system, concerning its contribution to the monitoring of nutritional disorders in Brazil as a base for public policies and interventions.

\section{Methods}

A mixed-method approach with triangulation of results was chosen to provide a more in-depth comprehension of the nutritional surveillance system, than a purely quantitative or qualitative analysis would bring individually [16]. The use of mixed methods has increased in the field of public health research, combining numerical and non-numerical results [17]. 
For the determination of coverage, a descriptive epidemiological study was conducted, based on secondary data analysis collected for the nutritional data of children (5 to 9), from all states in Brazil from 2008 to 2018. The data was collected from various Brazilian databases available online: Sisvan Web; Sisab (Primary Health Information Database); IBGE (Brazilian Institute for Statistics and Geography); Agência Nacional de Saúde Suplementar (National Complementary Health Agency) and the National Health Information Database (Datasus).

The indicators used in this analysis were: (i) national coverage of nutritional status of children in all federal states from 2008 to 2018 - percentage of children accompanied in the Sisvan, calculated as the number of children (5-9) registered in the system divided by the population of children that use the public health service in the same age group in those years, multiplied by 100; and (ii) completeness of data - obtained by dividing the number of municipalities that had registries in the system per year, by the total number of municipalities that could have registered per year, multiplied by 100 .

The data was analyzed using descriptive statistics, and the graphs were created using Microsoft Excel 16. The maps of coverage throughout the years were done in the TabWin 4.15 program.

For the qualitative part, interviews were conducted and the phenomenographic approach was chosen for analysis. The choice for this method derives from the objective, which was to "explore the perception" of the interviewees concerning the nutritional surveillance system. Phenomenography, a qualitative research method developed by researchers from the Swedish University of Gothenburg [18], centers the analysis on the relationship between the subject and his/her experience of the phenomenon [19]. As Marton, one of the precursors of this method describes, the process aims to map the different ways in which people "experience, conceptualize, perceive and understand various aspects" of the phenomenon in question [20] The application of the phenomenographic approach in the field of health care brings many opportunities, for it seeks to describe patterns and differences in the way people understand or ascribe meaning to the experiences around them, bringing a holistic perspective to the research [18].

A total of nine in-depth interviews were conducted with professionals working directly with the Sisvan representing different spheres (municipal, state and federal). This choice was made in order to gain a variety of perspectives regarding the system, with various levels of expertise and understandings, as the phenomenographic method indicates that sufficient variation in the ways of seeing the phenomenon is necessary [21]. In this case, limitations on sample size were required to make the research feasible in the scope of time and resources.

The focus of the interviews was to encourage the interviewees to reveal their understandings of the functioning and usage of the nutritional surveillance system Sisvan and encourage them to disclose the context for which it is used and their experiences with its implementation. A guide with questions was developed, tested and approved during the first interview and used in all the following interviews and participants were given the opportunity to add information and experiences based on their perceptions. The interviews were transcribed verbatim and the analysis began with an initial reading of all nine transcripts as a whole, attempting to perceive the significant and similar contexts that emerged from this 
process [22]. Subsequent readings followed with a focus on the phenomenon in question. The coding process was done with exporting the transcribed data into MAXQDA 2020. The researcher created a total of 95 codes and these were then organized within eight categories.

Triangulation of results was used as a final method, in order to find convergent or dissonant themes in the different methods [23] and as a means to secure a more in-depth analysis of the Sisvan. As a methodology for the triangulation, a choice was made for the triangulation protocol developed by Farmer et al, which fits the phenomenographic approach of identifying key themes.

\section{Results}

\subsection{Quantitative Results}

The total coverage of nutritional status of children in the system was calculated by state, as demonstrated in Table 1 below. The states in the North and Northeast region of the country presented the greatest annual variation on coverage (+2,788; Cl95\%: 2,29;3,29 and +2,784; Cl95\%: 2,49;3,07 - change in percentage points respectively) and the States of Amazonas and Tocantins in the North region had the greatest variation. The national coverage went from 14,2\% in 2008 to 35,8\% in 2018 (see Table 1). 
Table 1

- Average annual variation of coverage of data on nutritional status of children within Sisvan by state

\begin{tabular}{|c|c|c|c|c|c|}
\hline \multirow[t]{2}{*}{ State } & \multirow[t]{2}{*}{$\begin{array}{l}\text { Municipalities } \\
\text { (n) }\end{array}$} & \multicolumn{2}{|c|}{$\begin{array}{l}\text { Annual Coverage of the } \\
\text { nutritional status of children } \\
5-9 \text { years old (in \%) }\end{array}$} & \multirow[t]{2}{*}{$\begin{array}{l}\text { Average annual } \\
\text { variation (in } \\
\text { percentage points) }\end{array}$} & \multirow[t]{2}{*}{ Cl 95\% } \\
\hline & & 2008 & 2018 & & \\
\hline \multicolumn{2}{|l|}{ North Region } & 15,37 & 41,39 & 2,788 & 2,$29 ; 3,29$ \\
\hline Acre & 22 & 14,07 & 40,57 & 3,330 & 2,$52 ; 4,14$ \\
\hline Amapá & 16 & 6,64 & 26,74 & 2,106 & 1,$67 ; 2,51$ \\
\hline Amazonas & 62 & 16,42 & 46,95 & 3,649 & 2,$74 ; 4,55$ \\
\hline Pará & 144 & 16,23 & 42,61 & 3,275 & 2,$33 ; 4,22$ \\
\hline Rondônia & 52 & 12,01 & 23,53 & 1,467 & 1,$12 ; 1,81$ \\
\hline Roraima & 15 & 13,02 & 31,69 & 2,151 & 1,$23 ; 3,07$ \\
\hline Tocantins & 139 & 17,98 & 50,06 & 3,539 & 2,$97 ; 4,11$ \\
\hline \multicolumn{2}{|c|}{ Northeast Region } & 19,2 & 43,09 & 2,784 & 2,$49 ; 3,07$ \\
\hline Alagoas & 102 & 19,23 & 41,24 & 2,638 & 2,$02 ; 3,26$ \\
\hline Bahia & 417 & 19,19 & 39,68 & 2,445 & 1,$82 ; 3,07$ \\
\hline Ceará & 184 & 21,63 & 45,64 & 3,031 & 2,$25 ; 3,81$ \\
\hline Maranhão & 217 & 21,46 & 47,79 & 3,243 & 2,$32 ; 4,17$ \\
\hline Paraíba & 223 & 24,46 & 45,72 & 2,296 & 1,$65 ; 2,94$ \\
\hline Pernambuco & 185 & 12,49 & 39,6 & 2,682 & 2,$23 ; 3,13$ \\
\hline Piauí & 224 & 21,61 & 52,44 & 3,386 & 2,$62 ; 4,15$ \\
\hline $\begin{array}{l}\text { Rio Grande } \\
\text { do Norte }\end{array}$ & 167 & 17,75 & 36,97 & 2,218 & 1,$45 ; 2,94$ \\
\hline Sergipe & 75 & 15,1 & 44,6 & 3,118 & 2,$40 ; 3,84$ \\
\hline \multicolumn{2}{|c|}{ Mid-West Region } & 9,15 & 28,14 & 2,090 & 1,$44 ; 2,73$ \\
\hline $\begin{array}{l}\text { Distrito } \\
\text { Federal }\end{array}$ & 1 & 2,2 & 14,47 & 1,340 & 0,$96 ; 1,72$ \\
\hline Goiás & 246 & 10,65 & 25,89 & 1,594 & 1,$19 ; 1,99$ \\
\hline $\begin{array}{l}\text { Mato } \\
\text { Grosso }\end{array}$ & 141 & 9,49 & 36,98 & 2,841 & 2,$25 ; 3,43$ \\
\hline
\end{tabular}




\begin{tabular}{|c|c|c|c|c|c|}
\hline \multirow[t]{2}{*}{ State } & \multirow[t]{2}{*}{$\begin{array}{l}\text { Municipalities } \\
\text { (n) }\end{array}$} & \multicolumn{2}{|c|}{$\begin{array}{l}\text { Annual Coverage of the } \\
\text { nutritional status of children } \\
5-9 \text { years old (in \%) }\end{array}$} & \multirow[t]{2}{*}{$\begin{array}{l}\text { Average annual } \\
\text { variation (in } \\
\text { percentage points) }\end{array}$} & \multirow[t]{2}{*}{$\mathrm{Cl} 95 \%$} \\
\hline & & 2008 & 2018 & & \\
\hline $\begin{array}{l}\text { Mato } \\
\text { Grosso do } \\
\text { Sul }\end{array}$ & 79 & 10,96 & 33,98 & 2,583 & 2,$21 ; 2,96$ \\
\hline \multicolumn{2}{|c|}{ Southeast Region } & 10,81 & 27,92 & 1,797 & 1,$16 ; 2,43$ \\
\hline $\begin{array}{l}\text { Espírito } \\
\text { Santo }\end{array}$ & 78 & 16,81 & 24,93 & 0,969 & 0,$56 ; 1,37$ \\
\hline $\begin{array}{l}\text { Minas } \\
\text { Gerais }\end{array}$ & 853 & 16,05 & 42,05 & 2,867 & 2,$29 ; 3,44$ \\
\hline $\begin{array}{l}\text { Rio de } \\
\text { Janeiro }\end{array}$ & 92 & 7,85 & 22,96 & 1,822 & 1,$12 ; 2,52$ \\
\hline São Paulo & 645 & 8,12 & 21,83 & 1,529 & 1,$20 ; 1,85$ \\
\hline \multicolumn{2}{|c|}{ South Region } & 11,51 & 29,15 & 1,848 & 1,$48 ; 2,21$ \\
\hline Paraná & 399 & 11,77 & 29,23 & 1,806 & 1,$23 ; 2,38$ \\
\hline $\begin{array}{l}\text { Rio Grande } \\
\text { do Sul }\end{array}$ & 497 & 12,88 & 27,6 & 1,595 & 1,$21 ; 1,98$ \\
\hline $\begin{array}{l}\text { Santa } \\
\text { Catarina }\end{array}$ & 295 & 8,6 & 31,33 & 2,143 & 1,$55 ; 2,73$ \\
\hline Brazil & 5570 & 14,2 & 35,81 & 2,432 & 2,$16 ; 2,71$ \\
\hline
\end{tabular}

The average annual variation was calculated using linear regression, considering all years between 2008 and 2018. In this table, only the first and last years are demonstrated. In general, all states demonstrated an increase on the average coverage throughout the period of 11 years (2008-2018). The North and Northeast regions remain with greatest coverage overall, as illustrated as well in the maps of Fig. 1 below.

On the other hand, the average participation of data originating from the Bolsa Familia program within the system has a decrease from $91.81-74.63 \%$ with a steady decrease after 2014 (see graph 1 below).

For the completeness of data, the number of municipalities with no entries was calculated by state. In all years, except for 2017, there were at least one municipality with missing data for nutritional surveillance of children. From 2011 onwards, the percentage of missing data stays below $1 \%$.

\subsection{Qualitative Results}

Based on the analysis of the interview material, eight categories of description were created with the coding process, which are described below. 
Category 1 - Process of data collection is perceived as technically simple, but still challenging in the overall process.

Each municipality in Brazil has autonomy to decide on the process of collecting and processing data for the Sisvan system. Some municipalities are organized with a specific coordination for food and nutritional surveillance while others are not. This, as well as the existence of local health information systems influences on the way data is collected. There was mention of lack of uniformity within the same municipality (given the organization and structure of each health unit), as well as low data collection and general challenges regarding the data collection process. At the same time, the system is described as intuitive and simple to use, with instant return of data.

"At the moment I pass it on to the system, there's a first analysis, which I will see if there's any serious disparity. Then since it's online this data goes automatically to the ministry of health. So if today I enter data and tomorrow I want a report on these data, I have it. It's instantaneous." (6)

On the other hand, challenges related to data collection, low coverage, lack of interest from professionals or even the decentralization of the systems are mentioned as having an effect on the results, which shows there is still room for improvement.

"Each municipality decides for themselves, so each one does it one way, fills it out as they want it. There are towns that work really well and others don't."(3)

Besides the nutritional status indicators (measurements of height and weight), the Sisvan accompanies food consumption, which is a form with a 24-hour recall, with yes and no questions regarding the food habits for children less than 6 months, 6 to 23 months and children over 2 years old, teenagers, adults, pregnant women and elderly. The food consumption form has been described as easy, although seen as a challenge among the participants, presenting very low coverage and a burden to professionals to fill out.

"The questionnaire on nutritional intake, which is part of the Sisvan, needs to be used more. There still is a resistance to use the questionnaire on nutritional intake because it requires more time to do those questions." (7)

\section{Category 2 - Sisvan as a guide for programs and policies requires a cross-sectional approach and identification of problematic issues.}

It is clear that the system is characterized as a tool to visualize and monitor the current status of the population attended by the Primary Health care units. The perception of the Sisvan's objective to serve as a guide for policy making is evident, although more articulation between the different instances (municipal, state and federal) could aid the municipalities to create or adapt more local programs with the generated data. 
"I think it provides information for municipalities, state, and national. The transformation, our work begins here in our town, at the primary care. So I think each sector is responsible." (2)

Data generated by the system are seen as an important asset both locally as beyond the municipality and the health sector. Even if they presented challenges in terms of transposing this data into programs and policies, it is clear that there's a concern in generating results with the information provided by the Sisvan, as well as collecting precise data which can be used by third parties. The challenge is the lack of time or priority given to the local usage of the collected data. Partnerships with the academic sector, for example, is a possibility for these municipalities to be able to reflect and analyze the results. A third-party with more resources can assist the health units and departments in this matter and would fill the gap some of them perceive of this lack of local analysis and usage of the results.

"With the University for example, we started doing inter-sectorial work, and we ask as a counterpart, this study of these data the town is producing. So we have a better view of what's going on." (2)

\section{Category 3 - Perceived local ownership of data influenced by decentralization of health system.}

The Sisvan is regarded by the participants as key for municipalities to monitor the populations' nutritional status and articulate to existing or new programs and public health practices. There is a common view of the system as a local tool for health unit managers to diagnose and have the necessary information for priority settings and interventions. It was possible to detect in the interviews a direct link made from Sisvan generated data to individual accompaniments, which is an indication that local ownership of data does takes place. By local ownership here it is meant the collective process in which local actors determine and influence in the production of health agendas based on produced data $[24,25]$.

"I see as a main characteristic or function of the system to allow for anyone to look at this nutritional situation diagnosis to plan actions related to and focused on health issues related to that specific unit or municipality." (3)

"it was based on this analysis that we were able to justify the implementation of a program to treat obesity. Because it demanded resources, inter-sectorial work, we involved different departments." (2)

Local management can benefit from analyzing their own collected data, although it does not appear to happen frequently and local analysis depends on how each individual health unit or even the municipality is organized. The process of actively using this data locally still has room for improvement, since it is not frequent for individual health units or managers to monitor their local needs.

"So the health teams many times do not have time to look at this data because we know how demanding is the health teams' routine." (7)

Participants describe the system as giving the possibility of a local diagnosis for a specific region or health unit but this is counterbalanced with the difficulties found in the day to day operations of the 
primary health care centers, which are burdened with other responsibilities that overshadow the nutritional surveillance development.

"The professionals they screen the materials, the documents to fill out. So they fill out those they believe are most important, more demanded by the management staff, and they leave out the ones that are not so demanded, in part, or think it's less interesting." (5)

The local ownership of the generated data is also related to the effects of the decentralized health care setting, in which each municipality is organized in a different way and has the ability to plan and demand information according to the way the health departments are structured.

\section{Category 4 - Sisvan is an embedded part of the National Health Information System}

Participants perceived a greater relationship between the nutritional surveillance to the other health information systems present in the primary health care setting. There is an ongoing interoperability, which allows transfer of information between the information systems available in the basic health units, where the data is collected.

"...the path I think is to increasingly have an integration of data which I think it's essential, thinking also on the local manager, because it avoids double work, and gives a return both general and specific."(8)

Even though some municipalities use other information systems within the health units that are not the national Sisab platform, they integrate the systems so that all collected data migrates to the e-sus system (which is the national information system within the Primary Care, as an attempt to digitalize and qualify the work process. Municipalities can use their own system of information, given data are later entered into the main database). This, on the other hand, brings some challenges as well and potential "data loss".

Eventually, the Sisvan appears as a system that can aggregate data from all other information systems, which can bring benefits in terms of data analysis, if used in its potential.

"Today the Sisvan is really for a management of all this information from various systems or these accompaniments that take place in the basic health units in the municipalities". (9)

\section{Category 5 - Existing integration into the Primary Health Care and Family Health Strategy is evident, but at the same time reveals challenges and difficulties of daily routine.}

The Primary health care system in Brazil has advanced greatly in the last years, especially with the expansion of the Family Health Strategy, which makes the bridge between the population and the health units, and the cash transfer social programs [26]. The Family Health Strategy (FHS) works in teams, composed of a minimum of one doctor, one nurse, one auxiliary nurse and Community Health Agents. These teams were expanded in the year 2000 [27] with a new structure to include a multidisciplinary team with dentists, nutritionists, psychologists, social workers and others - which compose the Nucleos de 
Apoio à Saude da Familia - NASF (Family Health Support Nucleus). These nucleus are responsible for several health units and have a rotation schedule, depending on the municipality, the population size and local organization. The Sisvan system appeared as a routine process within the primary health care units and in some cases, the NASF teams were pointed as being the ones responsible for the data collection, given a nutritionist is part of the groups.

"It's done in the basic health unit, so every user that comes to the health unit in the consultation, they do the anthropometric measurement and food consumption through the Sisvan-web" (5)

The PSE Program (Programa Saúde na Escola or School Health program), established in 2007 also appears to be articulated to the Sisvan system, for measuring teenagers and young children. This integration to the Primary health care system, at the same time that it characterizes the system as routine, also demonstrates challenges which are common to all information systems and services, such as a work overload for the health professionals and the impossibility of using the Sisvan to all its potential.

"No one wants to feed any system, especially one such as this one, that doesn't result in a gratification for the employee because then they don't want it" (1)

"You end up piling up functions, so you don't stay directed towards the Sisvan. So for example, I'm a nurse, so I'm working with the Sisvan, the Bolsa, child formulas, obesity treatment, we aggregate activities and responsibilities". (2)

\section{Category 6 - Intertwining relationship between the Sisvan and Bolsa Familia.}

The Family Allowance program and the Sisvan appear to be mistaken for each other, but at the same time, are regarded as two different entities that dialogue only at a system level. The Sisvan's first digital version in 2003, Sisvan-web, was developed based on an existing structure for the cash transfer program Bolsa Alimentação (Food Allowance), a precursor of the Family Allowance (Bolsa Família) program. So when the Family Allowance was launched in 2004 and the nutritional status evaluation was a conditioning factor in health prevention to receive the benefit, the Sisvan was chosen as the management tool to gather this data [28]. The fact that a high percentage of the coverage of the Sisvan today is from data coming from the Bolsa Familia program is still due to a priority given to the measurement of the population receiving the benefits. This will have a repercussion as well on the representativeness of the generated data.

"So it ends up being that priority group which has information on food and nutritional surveillance, children, pregnant women and the beneficiaries from the Bolsa Familia, which is the conditionality of the benefit." (7)

Another factor which appears to influence this preference to the Bolsa Familia population is the immediate and palpable result of this process. 
"When they do the Bolsa Familia [measurement], they finish doing that and they already have an answer, because you fill it out, the family receives money. So they see a physical answer for that work they did. The Sisvan, its answer is not tangible, that's why they consider it less important." (6)

\section{Category 7 - Role of the State and Ministry levels of supervision and guidance has shortcomings.}

As the data collection takes place within the local municipal primary care setting, the States and Federal Ministry of Health play a guiding and supporting role in the process of collection and data analysis.

"In the process of collecting data, the role [of the ministry] is to induce. To show look, professionals, managers, we established a new tool, provided a new resource within the system, use it, doing the trainings, the disclosure notes, mechanisms of promotion to these professionals, and also solving doubts related to the use of the system." (9)

The State entities work as a "buffer" zone between the municipalities and the federal coordination of the system. State authorities also have a role of guiding and supervising the municipal data collection, although in a more in-person manner, emphasizing the importance of local authorities taking ownership of the information to guide policies and programs on a local level. However, this function played by the higher instances in the system's process also has flaws, as lack of guidance and proper training.

"There's no guideline, within the ministry of health, or the health departments, of who should fill this out. It's a system that is thrown out there and do whatever you want with it." (3)

\section{Category 9 - First stage of the Covid-19 pandemic has direct effect on system's coverage and role.}

All participants mentioned direct effects of the 2020 Covid-19 pandemic in their work, especially in terms of the data collection taking place within the primary health care setting. Since the measurements for the Sisvan are done within the health units and the population is not attending routine care, this will have a direct repercussion in the coverage. However, there has been a decision from the Ministry of Health to suspend the measurements for the first part of the year, so families are not penalized (Ministry Social Development, 2020) with the lack of cash transfer (in the case of the Family Allowance measures).

"Data will decrease, now in 2020 we'll have much less data, both from Bolsa Familia as the Sisvan, because people are not going to the health units." (3)

"One of the actions in our town to fight the virus was the suspension of routine consultation. We kept the prenatal visits, high blood pressure and diabetic patients, but the routine consultations we did this was all suspended. Measurements for the Bolsa, all this was cancelled, it was all was affected. We no longer do health promotion." (2)

On the other hand, the role of the nutritional surveillance system is seen as of great importance once the pandemic in Brazil diminishes, in order to accompany those families that have been economically affected during the crisis. 
"there will be an impact on the anthropometric data and the Sisvan will be able to map this. In a later period, in children we'll probably see an increase in terms of low weight, but it's a way to monitor this and identify priority groups for intervention." (8)

From the analysis of these categories, two great "forms of thought" [29] were derived, which describe the way the interviewees interpret the nutritional surveillance system. The two themes which constitute the experiential description of the phenomenon are:

\section{Sisvan is perceived as a path, or process, to generate data which can become action that transforms health}

The surveillance system was ultimately characterized as a "course of action". And this course can generate direct and positive results in terms of public health care to both individuals and collective entities or it can be just a routine data collection, which serves to fill a larger system of data that is used for diagnosis. In both cases, the Sisvan is seen as a "path", not an end in itself, which is a means to improve nutrition and health conditions. However, as a process, the system also has room for improvement, since it is in constant use and analysis. Challenges were presented in terms of data usage, analysis and the structuring and functioning of the system.

\section{Sisvan is part of a greater structure of care, that goes beyond nutrition}

Once the system is integrated within the Primary health care setting, within the health information system, it acquires relations to other programs, strategies and actors which define its role of not only a monitoring tool for the determining factors of nutritional status and habits of the population but also as one more fiber of the national health care fabric. This integration into a greater structure also imposes a demand for more articulation between several instances to generate results in the health setting.

\subsection{Triangulation of Results}

This part of the analysis was focused on determining key themes from both methods which could approached and tested for convergence or dissonance, according to the triangulation protocol developed by Farmer et al., 2006. The main topics that were found to be present in both methods (quantitative and qualitative) are: "low coverage of data"; "high prevalence of data from the Bolsa Familia program"; "uniform data collection in municipalities"; "system as part of the primary care with capillarity in all regions". These were assessed based on their convergence, agreement or dissonance [23] and the major results of this process is described in Table 3 , below: 
Table 3

- Summary of Triangulation of Results

\begin{tabular}{|c|c|c|c|}
\hline $\begin{array}{l}\text { Major } \\
\text { Themes }\end{array}$ & Quantitative & Qualitative & Convergence assessment \\
\hline $\begin{array}{l}\text { Low } \\
\text { Coverage } \\
\text { of data }\end{array}$ & $\begin{array}{l}\text { System present } \\
\text { in all Brazilian } \\
\text { states, but } 44 \% \\
\text { of the states } \\
\text { had coverage } \\
\text { of less than } \\
30 \% \text { in } 2018 \text {. }\end{array}$ & $\begin{array}{l}\text { Coverage } \\
\text { addressed by } \\
\text { interviewees as } \\
\text { a flaw and } \\
\text { influencing } \\
\text { factor in the } \\
\text { diagnosis of } \\
\text { results. }\end{array}$ & $\begin{array}{l}\text { A partial agreement was determined between the } \\
\text { two analysis. This is characterized by the fact } \\
\text { that even though low coverage of data was } \\
\text { detected in both methods, being an influencing } \\
\text { factor in the diagnosis of results, in the } \\
\text { qualitative study, low coverage was also stressed } \\
\text { as being a characteristic of the food } \\
\text { consumption part of the Sisvan, which was not } \\
\text { contemplated in the quantitative analysis of this } \\
\text { study. }\end{array}$ \\
\hline $\begin{array}{l}\text { High } \\
\text { prevalence } \\
\text { of data } \\
\text { from the } \\
\text { Family } \\
\text { Allowance } \\
\text { program }\end{array}$ & $\begin{array}{l}\text { Data } \\
\text { originating } \\
\text { from the Bolsa } \\
\text { Familia system } \\
\text { constituted } \\
91,8 \% \text { of the } \\
\text { data in } 2014 \\
\text { and } 74,6 \% \text { in } \\
2018 .\end{array}$ & $\begin{array}{l}\text { The Family } \\
\text { Allowance } \\
\text { program } \\
\text { appeared to be } \\
\text { identified as a } \\
\text { different } \\
\text { system but } \\
\text { with } \\
\text { interconnecting } \\
\text { relationship, } \\
\text { especially at } \\
\text { the data } \\
\text { collecting } \\
\text { process. }\end{array}$ & $\begin{array}{l}\text { There was agreement between both analysis } \\
\text { regarding this theme. It is clear that the Family } \\
\text { Allowance program plays an important part as a } \\
\text { booster for the high accompaniment of children } \\
\text { within the system, but this could have an } \\
\text { influence on the type of generated data } \\
\text { (convenient sampling). }\end{array}$ \\
\hline $\begin{array}{l}\text { System as } \\
\text { part of the } \\
\text { primary } \\
\text { care with } \\
\text { capillarity } \\
\text { in all } \\
\text { regions }\end{array}$ & $\begin{array}{l}\text { As of } 2015, \\
\text { only one region } \\
\text { of the country } \\
\text { had lack of } \\
\text { data in the } \\
\text { system. In } \\
2018 \text {, all but } \\
\text { one of the } \\
5.570 \\
\text { municipalities } \\
\text { of the country } \\
\text { had entered } \\
\text { anthropometric } \\
\text { data for } \\
\text { children. }\end{array}$ & $\begin{array}{l}\text { It is clear that } \\
\text { data collection } \\
\text { takes place } \\
\text { within the PHC } \\
\text { system and } \\
\text { that the } \\
\text { municipalities } \\
\text { have } \\
\text { engendered the } \\
\text { data collection } \\
\text { process within } \\
\text { the routine of } \\
\text { the health } \\
\text { units. }\end{array}$ & $\begin{array}{l}\text { A partial agreement was found between the two } \\
\text { methods regarding this theme. Data collection is } \\
\text { routine among municipalities, generating nation- } \\
\text { wide data but an in-depth analysis of the } \\
\text { quantitative per state would demonstrate in more } \\
\text { details the relationship between the coverage of } \\
\text { the PHC for example and the Sisvan. For there } \\
\text { isn't a uniform data collection process within } \\
\text { each state, which would need to be further } \\
\text { investigated to find converging points and the } \\
\text { influencing factors within the PHC system. }\end{array}$ \\
\hline
\end{tabular}

\section{Discussion}

Results have illustrated that the annual coverage of the nutritional status of children in all states of Brazil, from 2008 to 2018 within the Sisvan has grown considerably. Nationally, the total coverage went from $14,2 \%$ in 2008 to $35,8 \%$ in 2018 , a $152 \%$ difference. Interviewees have corroborated that the nutritional status has become a routine process within the primary health care setting and the Health in School 
strategy, which could account for this change. However, considerations must be made, in that the total national coverage is still low, with data from less than $40 \%$ of children (5-9 years old) in 2018 . Only two federal states demonstrated coverage of over $50 \%$ at the end of this eleven-year period. These results are in accordance to previous studies that addressed the low coverage of the Sisvan system in Brazil [10, 12 , 14].

There was also an increased capillarity of the system throughout the years within all states of the country and as of 2015, all of them showed an improvement in terms of completeness of data. This stability in the number of towns providing information could be due to the process of data collection and perception of the system as a routine, as well as the continuous improvement and integration of all health information systems for the primary care.

There are regional differences in the coverage, and the North and Northeast regions of the country demonstrated greater variability, which has been appointed in other papers as possibly being related to certain factors - such as prioritization of health policies in the region, coverage of the Family Health Teams and the number of beneficiaries of the Family Allowance program [12]. States in both of these regions present the largest percentage of the population receiving the benefits - in Maranhão and Piauí, for example, both in the Northeast, $48 \%$ and $43 \%$ of the population are beneficiaries, respectively [30].

The relationship with the Family Allowance was extensively explored with the interviewees and point to a common "root". The history of the Sisvan system is also associated to several strategies and actions focused on fighting malnutrition in Brazil, as a way to provide data and priority setting for welfare programs [31]. As of 2004, the "surveillance" measures were expanded to include all phases of life and attempt to amplify the practices to incorporate data from all populations attended by the Primary Health, not only those in a vulnerable situation, such as those receiving welfare benefits [31]. So when municipalities preference or only measure those families and children covered by the social program, a convenient sample is automatically formed, preventing a portrait of the Brazilian population as a whole [12]. As detected in the analysis, there is a clear understanding of the role the Family Allowance has in increasing the coverage of the Sisvan, although a careful consideration of what the results mean in terms of representation of the Brazilian population is still a gap.

A deeper articulation with the Health in School programs in municipalities might be a way forward in this scenario (for the monitoring of children and teenagers), since with this program, there's the anthropometric measurement of children in all public schools taking part in the initiative. This could eventually increase the coverage and lower the exclusive participation of data from the Family Allowance (this has been demonstrated here as well, for in the last years, participation fell from $91 \%$ in 2014 to $74 \%$ in 2018). A more detailed study of the relationship between the coverage of the Health in school program and the nutritional surveillance would bring more light in this subject manner, providing insight into how much data is actually provided by this program.

Limitations to this study include the choice of analyzed data, sample size and the effects of the Covid-19 pandemic. First, in terms of inclusion of data, the calculation of the coverage for food consumption could 
have contributed to both the qualitative and quantitative data collected, for the nutritional habits play an important role in the health analysis of the population, so this inclusion would have been beneficial in the triangulation of the results. Also, a more in-depth analysis of municipal coverage could also indicate more clearly the non-homogeneous status of data collection, although this would not be feasible within the scope of this project. Secondly, the number of interviewees could have been larger if this project had more time and resources. It would also have been insightful to interview personnel that were not necessarily related to the Sisvan in each instance, so bringing other actors from within the primary health units to further analyze the reach and understanding of the system. Lastly, it is important to point out that the participants were selected and drafted during the first stage of the Covid-19 pandemic in Brazil, having a direct effect on the number of interviewees that were available to talk given the turmoil faced by the health system's staff in the country.

Regarding the impact of the Covid-19 pandemic, it was evidenced as a factor that characterized the Sisvan system as being part of the Primary Health Care strategy in Brazil. As other health prevention activities, the nutritional surveillance was paused as effective measures to stop the spread of the Coronavirus came into place. And as part of the PHC, as it becomes daily practice, it also runs into challenges given the several factors affecting the primary health care in Brazil, such as low stability of staff members, work overload, lack of qualified professionals [14], as well as general financial and organizational challenges [26].

The decentralization of the PHC strategy in Brazil includes also the decentralization of the surveillance systems, with local managements having a central role in the surveillance and control of diseases [32]. So the collection, analysis and ultimate usage of the system is under autonomy of each municipality, which can generate a high level of inequality within each state, given the size of the towns and even to an utmost extent, the level of engagement of local authorities. Even if documented previously that those responsible for the Sisvan don't consider its use for decision making and guiding municipal management practices [14], there's ultimate potential for this practice, as interviews have brought to light that the actual understanding of the staff members is consonant to the concept that surveillance "is not an isolated activity, but goes hand in hand with the formulation and execution of policy" [33]. The participants are aware of the ongoing effort of collecting, analyzing and intervening as the pillars for the nutritional surveillance. "So to act in the surveillance, it's much more than just using the Sisvan." (9)

\section{Conclusions}

Even though the knowledge regarding the different aspects of the Sisvan as a surveillance system exists, the road to action is still to be paved accordingly. Local analysis of data and the establishment of interventions based on them is still the main gap in terms of nutritional surveillance $[11,14]$. This relationship between the generated data and actual changes in policy is not as clear to be demonstrated [4] and more studies would be needed to further address this issue. 
As the majority of the information systems in Brazil were developed without the participation of state and municipal instances [13], their objectives and priorities take into consideration the ones determined on a central or federal level and municipalities usually don't even have the tools to actually understand what are the predominant health issues and priorities in their local settings [34]. Capacity building of both individuals and institutions at a local level is key to promote change and would need to be further enhanced so they have an active participation on the creation of these monitoring instruments [35].

As Brazil was the first country to make a commitment to the WHO within the decade of nutrition set of actions, including targets to increase the consumption of fresh foods, reduce the intake of sugary drinks and stop the rising levels of adult obesity [36,37], the demand for the nutritional surveillance has become ever more crucial. In the effort to achieve these goals, municipal authorities, as well as other actors (including civil society, national and international organizations and institutions) need to be aware of the levels of malnutrition and the Sisvan can be a central player in this process. If we are to produce results and increase health governance at the local and community level [38], the primary health care needs to be continuously strengthened and the Sisvan, as a tool for policy change, whilst a strong mechanism, still requires more integration between its central players to eventually translate data into action.

\section{Abbreviations}

Sisvan: Sistema de Vigilância Alimentar e Nutricional (Food and Nutritional Surveillance System); Sisvanweb - Digital version of the Sisvan; SUS: Sistema Único de Saúde (Unified Health System); Bolsa Família: Family Allowance program (federal cash transfer program); ESF: Estratégia Saúde da Família (Family Health Strategy); PHC: Primary Health Care; NASF: Núcleos de Apoio à Saúde da Família (Family Health Support Nucleus); PSE: Programa Saúde na Escola (Health in School program); e-sus: Information system for the PHC in Brazil; Sisab: Sistema de Informação em Saúde para a Atenção Básica (Primary Care Health Information System); Datasus: Departamento de Informática do Sistema Único de Saúde (SUS' Digital Department).

\section{Declarations}

\section{Ethics approval and consent to participate}

The participation of the interviewees in this research was voluntary and consent forms and authorizations were sent to each participant previously. Interviews were conducted online and only audio recordings were made. The data collected through these interviews was anonymized, as to ensure confidentiality of the participants. The study was approved both in the Ethics Committee at the AlbertLudwigs-Universität-Freiburg (no. 145/20), and in the Research Ethics Committee of the Moriah Hospital, Brazil.

\section{Consent for publication}

Not applicable. 
Availability of data and materials

All relevant data is included in the article.

\section{Competing interests}

The authors declare that they do not have any competing interests.

\section{Funding}

This research received no specific grant from any funding agency in the public, commercial or not-forprofit sector.

\section{Authors' contributions}

GN and AM designed the study. GN led the data collection, analysis, interpretation and drafting of the manuscript, with support from AM. Both authors read and approved the final manuscript.

\section{Acknowledgements}

The authors would like to express their gratitude to the participants, who accepted to take part in this study providing interviews, amid the turbulent times of the Covid-19 pandemic.

\section{References}

1. Devereux, S., Béné, C., Hoddinott, J. Conceptualizing COVID-19's impacts on household food security. Food Security. 2020; doi: 10.1007/s12571-020-01085-0;

2. Ribeiro-Silva, R. et al. Covid-19 pandemic implications for food and nutrition security in Brazil. Ciência \& Saúde Coletiva. 2020; 25(9):3421-3430.

3. Galicia, L. et al. Nutrition situation in Latin America and the Caribbean: current scenario, past trends, and data gaps. Rev Panam Salud Publica; 2016; 40(2):104-13.

4. Tuffrey, V., Hall, A. Methods of nutrition surveillance in low-income countries. Emerging Themes in Epidemiology. 2016; 13:4. doi: 10.1186/s12982-016-0045-z

5. Castro, IRR. Vigilância alimentar e nutricional: limitações e interfaces com a rede de saúde. Rio de Janeiro, Fio Cruz, 108p. 1995.

6. Coutinho JG., et al. A organização da Vigilância Alimentar e Nutricional no Sistema Único de Saúde: histórico e desafios atuais. Revista Brasileira Epidemiologia. 2009; 12(4), 688-699.

7. Ministry of Health, Brasil. Política Nacional de Alimentação e Nutrição. 2010. pg.34-35. http://bvsms.saude.gov.br/bvs/publicacoes/politica_nacional_alimentacao_nutricao.pdf Assessed 29 Nov 2019

8. Enes, C.; Loiola, H., Oliveira, MR. Cobertura populacional do Sistema de Vigilância Alimentar e Nutricional no Estado de São Paulo, Brasil, Revista Ciência \& Saúde Coletiva. 2014; 19(5), 1543- 
1551.

9. Ferreira, CS.; et al. Fatores associados à cobertura do Sisvan Web para crianças menores de 5 anos, nos municípios da Superintendencia Regional de Saúde de Belo horizonte, Brasil. Ciência \& Saúde Coletiva. 2018; 23(9): 3031-3040.

10. Damé PK. et al. Sistema de Vigilância Alimentar e Nutricional (Sisvan) em crianças do Rio Grande do Sul, Brasil: cobertura, estado nutricional e confiabilidade dos dados. Cadernos de Saúde Pública. 2011; 27: 2155-65.

11. Ferreira CS., Cherchiglia ML., César CC. O Sistema de Vigilância Alimentar e Nutricional como instrumento de monitoramento da Estratégia Nacional para Alimentação Complementar Saudável. Revista Brasileira Saúde Materno Infantil. 2013 13(2): 167-177.

12. Nascimento, F. et al. Cobertura da avaliazação do estado nutricional no Sistema de Vigilância Alimentar e Nutricional brasileiro: 2008 a 2013. Cadernos Saúde Pública. 2017; 33(12).

13. Branco, MA. Sistemas de informação em saúde no nível local. Cadernos de Saúde Pública. 1996; 12(2): 267-270.

14. Rolim MD., et al. Avaliação do SISVAN na gestão de ações de alimentação e nutrição em Minas Gerais. Ciencia e Saude Coletiva. 2015; 20(8): 2359-2369.

15. Denzin, NK. Triangulation 2.0. Journal of Mixed Methods Research. 2012; 6(2): 80-88. doi: $10.1177 / 1558689812437186$.

16. Santos, JLG., et al. Integração entre dados quantitativos e qualitativos emu ma pesquisa de métodos mistos. Texto Contexto Enfermidades. 2017; 26 (3). Doi: 10.1590/0104-07072017001590016

17. Tariq, S., Woodman, J. Using mixed methods in health research. Journal of the Royal Society of Medicine Short Reports. 2010; 0: 1-8. doi: 10.1177/2042533313479197.

18. Barnard, A, McCosker, H., Gerber, R. Phenomenography: A Qualitative Research Approach for Exploring Understanding in Health Care. Qualitative Health Research. 1999; Vol.9 (2): 212-226.

19. Cherman, A., Rocha-Pinto, SR. Phenomenography and the Valuing of Knowledge in Organizations: Dialog between Method and Phenomenon. RAC. 2016; Rio de Janeiro, v. 20, n. 5, art. 6, pp. 630-650.

20. Marton, F.Phenomenography-A Research Approach to Investigating Different Understandings of Reality. Journal of Thought. 1986; Vol. 21, No. 3, pp. 31

21. Bowden, JA., Green, P. Doing developmental phenomenography. Australia, RMIT University Press, 2005.

22. Åkerlind, G. Phenomenographic methods: A case illustration. In: Bowden, JA., Green, P., Doing developmental phenomenography. RMIT University Press, 2005.Pg. 103-127

23. Farmer, T., Robinson, K., Elliot, SJ., Eyles, J. Developing and Implementing a Triangulation Protocol for Qualitative Health Research. Qualitative Health Research. 2006; Vol. 16 No. 3, 377-394. doi: $10.1177 / 1049732305285708$

24. Vanyoro, KP. et al. Local ownership of health policy and systems research in low-income and middleincome countries: a missing element in the uptake debate. BMJ Global Health. 2019; 4:e001523. 
doi:10.1136/bmjgh-2019-001523

25. Lehmann, U., Gilson, L. Action learning for health system governance: the reward and challenge of co-production. Health Policy and Planning. 2015; 30; 957-963.

26. Macinko, J., Harris, MJ. Brazil's Family Health Strategy - Delivering Community-Based Primary Care in a Universal Health System. The New England Journal of Medicine. 2015; 372;23.

27. Melo, EA. et al. Changes in the National Policy of Primary Health Care: between setbacks and challenges. Saúde Debate. 2018; v.42(1): 38-51.doi: 10.1590/0103-11042018S103.

28. Camilo S.M., et al. Vigilância Nutricional no Brasil: criação e implementação do Sisvan. Revista de Atenção Primária à Saúde. 2011; 14(2), 224-228

29. Marton, F. Phenomenography - Describing Conceptions of the World Around us. Instructional Science. 1981; 10, 177-200: pg.180.

30. Arrais, TA. O Bolsa Familia e a tradução regional da questão social. Revista do Instituto de Estudos Brasileiros. 2016; n.65, p.200-226.

31. Ministry of Health, Brazil. Marco de Referência da Vigilância Alimentar e Nutricional na Atenção Básica. 2015.

http://bvsms.saude.gov.br/bvs/publicacoes/marco_referencia_vigilancia_alimentar.pdf Assessed 14 Nov 2019.

32. Teixeira, M. et al. Vigilância em Saúde no SUS - construção, efeitos e perspectivas. Ciência \& Saúde Coletiva. 2018; 23(6), 1811-1818.

33. FAO/UNICEF/WHO Expert Committee. Methodology of Nutritional Surveillance. World Health Organization Technical Report Series, N.593;1976.

34. Medici, A. C. Descentralização e informação em saúde. In: IPEA, Planejamento e Políticas Públicas. $1991 ; 5,5-29$.

35. Tuffrey, V. A perspective on the development and sustainability of nutrition surveillance in lowincome countries. BMC Nutrition. 2016;2:15. doi: 10.1186/s40795-016-0054-x

36. Longhi, L. A Década de Ação para a Nutrição: compromissos, desafios e o fortalecimento da saúde na agenda de segurança alimentar e nutricional.2018.

https://saude.gov.br/images/pdf/2018/outubro/22/20_Lorenza_Longhi.pdf Assessed 9 Aug 2020.

37. Ministry of Health, Brazil. UN Decade of Action on Nutrition. Brazil. SMART Commitments on Ending Obesity. 2017. https://www.who.int/nutrition/decade-of-action/brazil-commitment-22may2017/en/. Assessed 10 Jun 2020

38. Jeremie, N., Kaseje, D., Olayo, R., Akinyi, C. Utilization of Community-based Health Information Systems in Decision Making and Health Action in Nyalenda, Kisumu County, Kenya. Universal Journal of Medical Science. 2014; 2(4): 37-42. Doi: 10.13189/ujmsj.2014.020401.

39. Burt, J. Following the mixed methods trail: some travel advice. British Journal of General Practice. 2015, May;65(634):264-5. Doi: 10.3399/bjgp15X685045. 


\section{Figures}
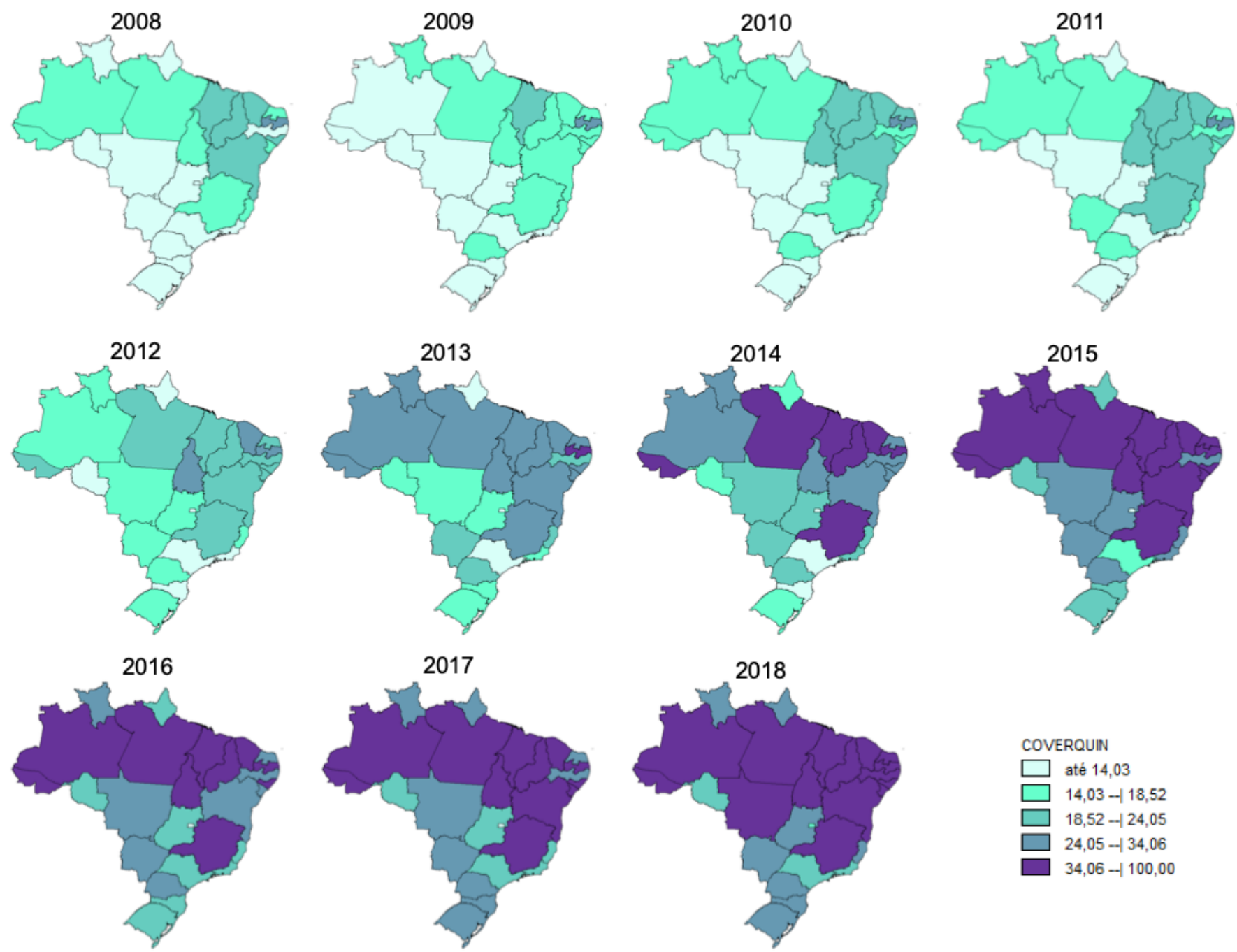

\section{Figure 1}

Annual coverage of the nutritional status of children within the Sisvan system, with divisions by state of the federation

\section{Supplementary Files}

This is a list of supplementary files associated with this preprint. Click to download.

- Graph1.png 